\title{
Principles of Culinary Dictionary Compiling
}

\author{
Rano Sayfullayeva, National University of Uzbekistan named after Mirzo Ulugbek Republic of Uzbekistan \\ Gulnoza Odilova , National University of Uzbekistan named after Mirzo Ulugbek Republic of Uzbekistan
}

\begin{abstract}
The article deals with the issues of analyzing the principles of creating a bilingual culinary dictionary, as well as similar and different aspects of the means of gastronomic terms in Uzbek and English. The paper presents a dictionary which contains several stages of cooking and gives their translation with special illustrations.
\end{abstract}

Keywords: dictionary, gastronomic terms, explanation, description, bilingual

Received: 09.12.2020 $\quad$ Accepted: 11.01.2021 $\quad$ Published: 07.02.2021

\section{Introduction}

A culinary encyclopedia is one of the most important tools of popularizing national cuisine to the world and plays a significant role in recreating ancient recipes, inform tourists widely with the culinary traditions of a nation.

Of course, the translator tries to translate the text according to the specifics of the text and linguistic features of a source language. Translation is not just a rendering of the source language. It's the art that requires the background knowledge of several disciplines. On the other hand, the translator must possess not only linguistic but also extralinguistic knowledge, study an unfamiliar area to explore it. One of the most important tools in translation work is the availability of a specialized terminological dictionary. We analyzed a number of recipes in our research and we discovered that the identified shortcomings are mainly related to the translation of gastronomic texts. The root of the problem is the lack of bilingual gastronomic dictionaries, the lack of a gastronomic terminological apparatus of the Uzbek and English languages. As we aim to create a menu that meets international standards, we feel a great need for a culinary glossary that includes a translation of specialized gastronomic vocabulary.

First of all, it is necessary to study the recipes in both Uzbek and English. During the preparation of the first culinary encyclopedia "Delicious Uzbekistan" we paid attention to these aspects.

In a traditional recipe written in the gastronomic lexicon, the ingredients are listed first and then the cooking process. The processes are reviewed sequentially. While the recipes for Uzbek national dishes are created in the same way, actions are expressed in the passive voice. For example:

1,5-2,0 кг ли куй ёки мол гуцшти тайёрланиб, қозондаги совуқ сувга солинади, қайнаш даражасига етказилиб, вақти-вақти билан юзидаги купиги сузиб турилади (Ўзбекистон ошпазлар уюшмасининг ягона базасидан).

In English recipes, in contrast to Uzbek, verbs are usually in imperative mood:

Soak the mushrooms in warm water, chop into pieces and mix them with the onion and butter in a microwaveable container; cover and cook for 4 minutes at $750 \mathrm{~W}$, stirring once halfway through. ("So delicious" USA, 2013)

Even when the above text is translated into English, the Uzbek equivalents are given in the imperative mood:

Take 1.5- $2.0 \mathrm{~kg}$ lamb or beef and put into a pot of cold water. Bring to boil and skim off the scum on the surface from time to time.

As a result, one sentence in Uzbek turns into several sentences in English. Therefore, the first step in compiling a dictionary is to learn the general syntactic features of a culinary language.

If we pay attention to the structure of the recipe, first a list of products is given, and then the cooking process is reflected. Likewise, a glossary should also be divided into several sections. In our opinion, it is advisable to divide it into the following parts:

The first section is a dictionary of product names.

The second section is a dictionary of kitchen utensils.

The third section is a dictionary of words used throughout the cooking process.

The fourth section is a dictionary of specially prepared names of semi-finished products.

The fifth section is the measurements units.

The first section, in turn, consists of several parts, that is, they are classified according to the type of product:

- Fruits 
- Vegetables

- Greens

- Meat products

- Dairy products

- Flakes

- Spices

- Other products

All products are listed alphabetically by category. In this process, it is recommended that you include the names of the products as they appear in the recipe. For example, in Uzbek, lamb is used with the word "sheep", but in English, the word "lamb" is used instead of "sheep meat" for mutton, since mutton is a "sheep"; the word "beef", not "cow meat" for beef; the word "chicken" is used to mean chicken, not "hen" because in Uzbek the meat of animals named with the noun (cow, sheep, hen+meat - for. eg: qo'y go'shti sheep meat; mol go'shti - cow meat). These aspects should also be taken into account when compiling a dictionary. In addition, some products are used in reality without translation into English. For example, since there is no English equivalent for "po'stdumba", you need to comment it out in the dictionary. The reason is that the buttocks and thighs of cattle and sheep are called "fat" in English. The product with high calorie (fat) usually is not consumed. Even when we observed this product were not on the shelves in US butcher shops. When we said that we needed sheep's buttocks, we saw that we could get this waste for free.

All gluttony nominees in the glossary are sorted alphabetically. Uzbek national dishes can be divided into subgroups: 1 . Uzbek national vegetable snacks. 2. Uzbek national meat and fish dishes. 3. Uzbek national soups. 4. Uzbek national appetizers. 5. Uzbek national second course dishes. 6. Uzbek national modern Uzbek dishes. 7. Uzbek national breads. 8. Uzbek national dough dishes. 9. Uzbek signature dishes and others.

The words used in it differ depending on the type of food. For example, in the text of an appetizer or recipe for national bread, there are practically no words denoting boiling in starters or frying in secondcourse dishes. So, the second part of the dictionary will be the translation of the kitchen utensils. Although the names of kitchen utensils are given in the dictionary, the most important aspect is the description of Uzbek national products, because they are national realias. For example, in the recipe for a wedding pilaf it is written that that rice is cooked in qozon o'choq. Its translation is not available in English. Because Uzbek national pot - kazan and o'choq - special oven is different from English oven. That is why the dictionary should provide information on the construction and meaning of the boiler/oven/pot.

There are also several types of tandoor: the oven in which the bread is baked differs in appearance from other types of bread. The mouth-up tandor is mainly used for baking somsa. In a tandoor oven, meat is usually cooked in a tandoor. The indicated types of tandoors should be reflected in the dictionary in the comments under the translation of this lexeme. Bowl for serving second-course dishes are translated into English as "plate". But the bowl is larger than the plate. Therefore, when translating the word "bowl" it should be noted that it is not the same as a plate. So, the most important aspect of this section is that with the correct translation of the name of each kitchen appliance of national importance, it is necessary to provide information about its characteristics. In the recipes for each type of food, all specific lexical items are again divided into separate categories. The focus is on the semantic aspect of words and compounds. They can be conditionally divided into the following categories: 1. Words related to decor. 2. Quenching. 3. Stirring. 4. Soaking. 5. Cutting methods, shape and size. 6. Dressings. 7. Fire levels. 8. Cooking standards. 9. Boiling. 10. Servings. 11. Roasting. 12. Methods of sprinkling (seasonings). 13. Serving the dish to the table. 14. Cleansing. 15. Time parameters. 16. Heating the oil. 17. Baking (tandor, plate). 18. Processes.

All words included in the third section of the dictionary are also arranged in alphabetical order according to this classification. The classification sequence is based on the cooking sequence, i.e. first a series of words related to cleaning, then cutting, cooking, frying, boiling, etc.

Decorating words are words and combinations that appear in all recipes. Therefore, they are universal. Decorating process is carried out in different ways: sprinkle food, water or cook any form of vegetables. These features are taken into account when compiling the dictionary.

For example, to season the dish with sauce or cream we use the verb "pour" in Uzbek. But we cannot translate it as "pour" when we put it in the dictionary. For this, a special prepositional phrase "drizzle with ..." is used in English. It is also important that the word is explained after its translation. This is where dividing this section into different parts comes in handy, and immediately identifies the difference between "drizzle with" and "pour". Among the words around a concepts we find a synonym that gives the same meaning to the word "pour" in the Uzbek language.

These are the words "braise" and "steam", which are actually different processes. In Uzbek, cooking a dish, frying it with the subsequent addition of water is also called "dimlash", and full steam cooking in a 
saucepan is also called "dimlash". In English, the word "braise" is used in the first case, and the word "steam" in the second. Therefore, these words also require a certain explanation in the dictionary.

The words that take up most of the cooking process relate to slicing. Slicing types differ from each other depending on the shape and size. In Uzbek recipes, the words "to'g'raladi", "kesiladi" are expressed not only by the word "cut" in English but also by different words depending on the type of product and the method of cutting it. In such cases, the translator must use his extralinguistic knowledge and know how to adapt the text. In the dictionary, all cut shapes in English must be reflected with a specific commentary, depending on the type of product. For example, consider an excerpt from the following pilaf recipe:

Тўғралган пиёз қозондаги қиздирилган ёғга солиб жазланади ва қайнатилган пўстдумбани 100150 граммли бўлакларга бўлиб, пиёзга қўшиб қовурилади. Пиёз қизарганда сабзи солинади ва бир - икки аралаштирилиб сув қуйилади (Ўзбекистон ошпазлар уюшмасининг ягона базасидан).

Word-for-word translation: The chopped onion is fried in hot oil in a pot and the boiled peel is cut into pieces of 100-150 grams and added to the onion and fried. When the onion is fried, add the carrots and mix one or two with water (from the base of the Association of Chefs of Uzbekistan).

It is not stated here exactly what shape the onion is sliced, but it is a mistake to translate it directly as "cut onion". If the words used to cut onions in the dictionary are given separately, it will be convenient for the user and when faced with such a situation, it will be translated as "sliced onion" as given in the dictionary. The second problem in the above mentioned recipe is using the words which means several the form of ingredients. For Uzbek receptor after "add carrot" it is understandable that the carrot should be julienned for frying in pilafs recipe, but in English it translator should write the cutting form of the carrot.

The translator also has to translate it as "julienned carrot" knowing the specifics of the dish. Therefore, the dictionary should take into account such case, provide information about some features of the dish, and include comments on the cut.

As pilaf is the king of the Uzbek national dishes, it is advisable to include it in the dictionary. Because it is clear that a foreign citizen who does not know the features of the national cuisine will face a problem in such cases, and the dictionary should be free of such shortcomings. Another such case is frying - the word "fry" in Uzbek is used for frying in both low and high fat. As a result, in many diets, fried lagmon is referred to as "fried noodles". After all, "fry" in English means frying in a lot of oil (like fried chips, fried chicken or fish) and the gastronomic portrait of this dish changes in the imagination of the chef. In the lagman cooking technique, it is fried in low fat, stirring, and finally heated on the fire. This process also adds a specific flavor to the food. This process is given in English by another phrase "stir fry", and the cook is well aware that this method uses less fat. There is also the word "sauté", which is used for frying, which refers to frying the product over medium heat with low fat.

In the Uzbek language, these processes can be expressed by such compounds as "past olovda" - "low heat", "kam yog' solib" - "with little oil". If the Uzbek food commentary is translated directly into English by copying the Uzbek food commentary construct to fry vegetables in low heat with less oil it would be an inaccurate translation. The reason is that in this case, "sauté vegetables" alone are sufficient and adequate in terms of gastronomic style. For this reason, the difference in the terminological apparatus of the preparation technique should be studied on a comparative basis and then included in the glossary. Another such case, which is mentioned in Uzbek recipes, is related to cutting into rectangular or cubic shapes.

We know that potatoes for Uzbek meal "mastava" are cut into small rectangles, medium cut for "moshkichiri", and large cut for potato pilaf. We believe that this should be stated in the dictionary, and we are in favor of which word to use in the construction, depending on the size of the cube, in the translation of this word.

In English, words related to sprinkling are often used with prepositions. These prepositions have their own rules of use and place. In the dictionary, it is therefore advisable to use these compounds with multiple dots. Information should be given as to which preposition each word is represented by and what meaning it may have when it comes with which preposition. Sometimes certain units that are synonymous with each other are applied depending on the product being sprayed. That is, we cannot use the second instead of the word used for the first. For example, in the process of sprinkling salt and sprinkling greens on food, different verbs are used for both. Although they are represented by a single verb in Uzbek, the prepositional "season with..." is used in English to sprinkle salt or spices; Sprinkling the product on the dish is expressed by the preposition "sprinkle with...". It is obvious that in the context in which these compounds included in the dictionary should be explained.

We mentioned above that the meaning of a word can vary depending on the context. The word "processing", which is also used in the cleaning process, has different meanings depending on which product it is used for. If it is used for rice, of course, it means "rinsing it apart", "washing" for vegetables, and "rinsing the root" for vegetables. It is translated into English as "sort and rinse rice" in the first case, 
"wash vegetable" in the second case, and "discard the stems of greens and wash" in the last case. As we can see, a sentence in Uzbek covers a number of actions in English. In such cases, the dictionary must explain how several meanings of such polysemantic words are used depending on the context.

In recipes, the cooking time of food also plays an important role, and their expression in English is always used with prepositions. This part of the dictionary also focuses on prepositions.

Гўшт қайнаб чиққандан сўнг чала пишган нўхат солиниб, 40-60 дақиқа паст хароратда милтиллатиб қайнатилади. (Ўзбекистон ошпазлар уюшмасининг ягона базасидан)

The term given in this example means "during" and is expressed by the English preposition "for":

After boiling, add half-cooked peas and simmer for 40-60 minutes on low heat.

In addition, the cooking times section includes not only compounds that indicate the exact time, but also key phrases that indicate when one process ends and another begins. Words related to the various processes involved in cooking are the most common lexemes, which occupy a significant part of the second section. When translating words, it is advisable to comment in some places so that the user can instantly understand what the process is. In this section, too, we encounter a synonymous state of words. For example, the verb "to crush" in Uzbek recipes is used in different words in English, depending on the product used. The verb "beat" is used to mean "to crush meat" because the meat is crushed and softened when struck. Crushing in a mortar is used with the verb "crush", a meaning often also expressed by the word toad. The verb "mash" is used to make puree. In addition, the Uzbek language also has the verb "maydalamoq", which is synonymous with the word "ezmoq", which is mainly applied to small products and is often translated as "grind". Therefore, it should be noted that these two words included in the dictionary are synonymous with each other.

The fourth section of the dictionary contains a translation of the names of semi-finished products specially prepared for cooking. The peculiarity of this section is that the words used in Uzbek are called by another name in English or these words do not exist in English at all. Therefore, the meaning of the given word and its features, as well as explanations of how it is prepared, play a key role in this section as well. The word "qiyma" in Uzbek recipes is used not only in relation to the state in which the meat is removed from the mincer, but also in relation to the name of the mixture made from minced products. That is why it is not translated into English as 'mince' but as "filling" or "stuffing".

To make the soup, first all the products except rice are fried and boiled in water. This semi-finished product is called "zirvak" in Uzbek. In English, however, there is no such word, so the word is a realia. This word, which is included in the dictionary, requires an explanation, and the explanation consists of information about what products it is made of and how it is prepared, and, of course, its specific features. In the preparation of Uzbek national liquid dishes, it is often preferable to add meat or chicken broth, rather than water. In English, this is expressed by the words "broth" and "bullion". While the products such as ugra, lagmon, chuchvara, dolma, and meatballs are also semi-finished products, it is advisable to include them in this part of the dictionary. It should also be noted that meatballs in Kashkadarya dialect are called "gilak" and the dish made from them is called "gilak soup". Therefore, when translating all products, it is important to give them a variant in other dialects. In general, a culinary glossary is essential not only for translating recipes, but also for writing menu comments when creating a new dish. The culinary glossary can also be attached to a gastronomic encyclopedia, a guide, and bilingual books on the subject. We recommend the following criteria when creating a culinary glossary:

- Finding exact equivalents of gastronomic terms;

- Comparative analysis of prescription clichés in the source language;

- Availability of all sections of the glossary (The first part - a dictionary of product names, the second part - kitchen utensils, the third - words used during the cooking process, the fourth - specially prepared semi-finished product names, the fifth - the section units of measurement).

- The glossary definitions should be written in a short and fluent language, including extra-linguistic factors, dialects of the people to whom the food belongs.

\section{References}

1. Irina Petrovska. Language standards of the gastronomic offer / DOI 10.20544/HORIZONS.A.20.1.17.P29 UDC 811.163.3'276.6:641 811.111'276.6:641 .

2. Collections of Uzbek national dishes recipes base of Cooks Association of Uzbekistan.

3. Different Types of Restaurant Menus. https://www.texascovers.com/5-different-types-ofrestaurant-menus/

4. Cooking terms. https://www.ruchiskitchen.com/cooking-terms/

5. Leynse W., Romona P. Food as Metaphor. Encyclopedia of Food and Culture. Gale, 2003. N. pag. Answers.com. Web. 8 Jan. 2011 
6. Delicious Uzbekistan. Culinary encyclopedia. Gastronomic / terminological dictionary and methodical additions. // Compilers: Odilova G., Umarov A., Umaraliev T. - Tashkent: TSU Publishing House, 2019. - 200.

7. Fayziyev Shokhrud Farmonovich Medical law and features of legal relations arising in the provision of medical services. International journal of pharmaceutical research Volume 11, Issue 3, July - Sept, 2019 P. 1197-1200 doi:10.31838/ijpr/2019.11.03.088 http://www.ijpronline.com/ViewArticleDetail.aspx?ID=11016

8. Bryanskaya Elena, Fayziev Shokhrud, Altunina Anna, Matiukha Alena Topical Issues of an Expert Report in the Process of Proving in a Criminal Examination. International Journal of Engineering and Advanced Technology (IJEAT) ISSN: 2249 - 8958, Volume-9 Issue-1, October 2019 5345-5349 DOI: 10.35940/ijeat.A2946.109119 content/uploads/papers/v9i1/A2946109119.pdf https://www.ijeat.org/wp-

9. Fayziev Shokhrud (2019) Legal Aspects of Transplantology in the Republic of Uzbekistan. Systematic Reviews in Pharmacy, ISSN: 0976-2779, Vol: 10, Issue: 2, Page: 44-47 doi:10.5530/srp.2019.2.08 1575419211.pdf?1586863081

10. Tulaganova, G. Some issues of observance of international legal norms of fight against legalization of criminal incomes in the Republic of Uzbekistan Journal of Advanced Research in Dynamical and Control Systems 12 (2 Special Issue), c. 143-155

11. Bazarova D. Some problems of counteracting crimes related to laundering of illegal proceeds in Uzbekistan Journal of Advanced Research in Dynamical and Control Systems. Volume 11, Issue 7, 2019, Pages 873-885 